\title{
Hairy Tongue - A Series of 4 Cases
}

\author{
Karthik Rajarammohan로 Mohan Narayanan², Ravikumar P. T. ${ }^{3}$, Saramma Mathew Fenn4, Sabitha Gokulraj ${ }^{5}$
}

${ }^{1}$ Department of Oral Medicine, Diagnosis and Radiology, Vinayaka Missions, Sankarachariyar Dental College, Vinayaka Missions Research Foundation (Deemed to Be University), Salem, Tamilnadu, India. ${ }^{2}$ Department of Oral Medicine, Diagnosis and Radiology, Vinayaka Missions, Sankarachariyar Dental College, Vinayaka Missions Research Foundation (Deemed to Be University), Salem, Tamilnadu, India. ${ }^{3}$ Department of Oral Medicine Diagnosis and Radiology, Vinayaka Missions, Sankarachariyar Dental College, Vinayaka Missions Research Foundation (Deemed to Be University), Salem, Tamilnadu, India. ${ }^{4}$ Department of Oral Medicine Diagnosis and Radiology, Vinayaka Missions, Sankarachariyar Dental College, Vinayaka Missions Research Foundation (Deemed to Be University), Salem, Tamilnadu, India. ${ }^{5}$ Department of

Oral Medicine Diagnosis and Radiology, Vinayaka Missions, Sankarachariyar Dental College, Vinayaka Missions Research Foundation (Deemed to Be University), Salem, Tamilnadu, India.

\section{INTRODUCTION}

The term black hairy tongue was first coined by Amatus Lusitanus in the year 1557.1 It is a reactive hypertrophy and defective desquamation of filiform papilla causing hair-like projections usually affecting the dorsum of the tongue. Hairy tongue is known by other names such as lingua villa nigrosa. Patients with Hairy tongue is usually asymptomatic but occasionally complaints of dysgeusia, Glossopyrosis, or Halitosis. The Glossopyrosis in Hairy tongue was probably due to the growth of candidal colonies, which causes burning sensation on the affected dorsum of the tongue.

Hairy tongue is a benign condition characterised by hypertrophy of Filiform Papilla on the dorsum of the tongue. Hairy tongue is prevalent among $0.4 \%$ among south Asian Population. Hairy tongue clinically appears as elongated hair like projections on the dorsum of the tongue which gets stained blackish brown due to the presence of carbon in the tobacco smoke.

\section{PRESENTATION OF CASE}

A 67-year-old male reported with a chief complaint of burning sensation of the tongue. History revealed that he had a deleterious habit of smoking beedi for past 42 years about 2 beedis per day. Intraoral examination revealed a brownish hair-like elongation of filiform papilla on the dorsum of the tongue. Correlating the history, a provisional diagnosis of hairy tongue was made. [Figure 1]

A 60-year-old male reported with a chief complaint of bad breadth emanating from his oral cavity. Intraoral examination revealed brownish discolouration and elongation of filiform papilla on the dorsum of the tongue. [Figure 2]

A 52-year-old male reported with a chief complaint of occasional burning sensation on the tongue. Intraoral examination revealed brownish discolouration and elongated filiform papilla on the dorsum of the tongue. [Figure 3].

A 72 -year-old male reported with a chief complaint of malodour emanating from his oral cavity. Patient is a beedi smoker for the past 60 years, smokes about 3 beedis per day. Intraoral examination revealed yellowish discolouration and hair like projections of filiform papilla on the dorsum of the tongue. [Figure 4] Correlating the history, intraoral clinical findings, and a provisional diagnosis of hairy tongue was made.
Corresponding Author:

Dr. Karthik Rajarammohan,

Reader,

Department of Oral Medicine Diagnosis,

\& Radiology, Vinayaka Missions,

Shankarachariyar Dental College,

Vinayaka Missions Research Foundation,

NH-47, Sankari Main Road, Ariyanoor,

Salem, Tamilnadu, India.

E-mail: drkarthik@vmsdc.edu.in

DOI: $10.14260 /$ jemds/2020/557

How to Cite This Article:

Rajarammohan K, Narayan M, Ravikumar $P T$, et al. Hairy tongue - a series of 4 cases. J Evolution Med Dent Sci 2020;9(35):25672570, DOI: $10.14260 /$ jemds/2020/557

Submission 11-06-2020,

Peer Review 23-07-2020,

Acceptance 29-07-2020,

Published 31-08-2020.

Copyright (C) 2020 JEMDS. This is an open access article distributed under Creative Commons Attribution License [Attribution 4.0 International (CC BY 4.0)] 

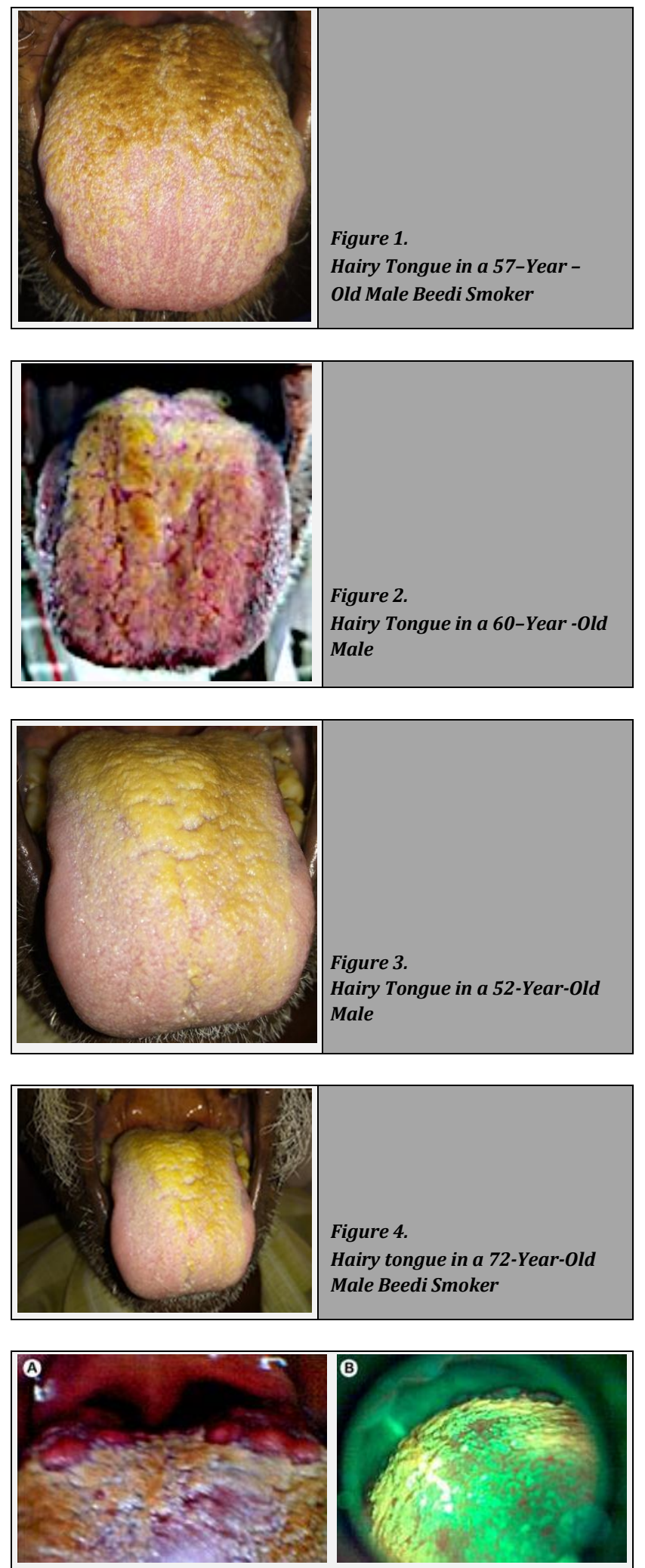

Figure 5. Wide Field Autofluorescence Device for the Diagnosis of Hairy Tongue

Image courtesy: Sérgio Araújo Andrade, Núcleo de Pesquisa em Química Biológica (NQBio), UFSJ - Universidade Federal de São João Del Rei, Divinópolis, MG, Brasil.

\section{DISCUSSION}

Hairy tongue was first reported by Gurvis et al. Hairy tongue was known by other names such as lingua villa nigrosa. Hairy tongue is a reactive hypertrophy of filiform papilla on the dorsum of the tongue. Hairy tongue commonly seen among smokers. Gurvis et al. reported that casual smoking poses a slightly increased risk of having black hairy tongue compared to non-smokers $(15 \%$ to $10 \%$ in men, $5.5 \%$ to $5.2 \%$ in women). ${ }^{1}$ In 1931 Henry corsi reported 2 cases of black hairy tongue. In 2004, Cheshire WP reported Unilateral black hairy tongue in trigeminal neuralgia patients as a result of avoidance of rubbing of tongue against the teeth due to the presence of trigger zones on the tongue that prevented normal desquamation of filiform papilla. ${ }^{2}$ In 2005 , Black Hairy tongue was reported during the treatment of Tuberculosis (Physiatric practice). ${ }^{3}$ Pipli $\mathrm{C}$ et al implicated that sunflower seeds causes Black Hairy tongue who ate sunflower seeds for 2 hours while watching television. ${ }^{4}$ In 2008, Pigatto et al reported cases of Hairy tongue with long term use of Macrolide antibiotic erythromycin. ${ }^{5}$ In 2008 Refaat et al and in 2010 Jover Diaz et al reported cases of black hairy tongue after consumption of drug Linezolid.5,6 In 2009 Tamam et al reported Hairy tongue among patients with excessive consumption of tricyclic antidepressants olanzapine. ${ }^{7}$ In 2010 Akay BN et al reported Hairy tongue after allogenic stem cell transplantation. ${ }^{8}$ In 1901 Lucet identified it as yeast cells and named it as cryptococcus linguae pilosae. Buxton in 1925 reported this peculiar lesion on a 64 year old male during routine examination of the tongue as a thin, hair-like processes, about one-third of an inch long, cover the center of the dorsum over an area in front of circumvallate papilla which is blackish in colour, feels soft, and there is no induration. Ralph found a symbiosis of a Cryptococcus with a nocardia growing in very fine filaments of stained hypertrophied filiform papilla in 1931. Barnard believes it as a disease of old age due to normal rubbing of hard food. An acid reaction of the mouth seems to be the essential underlying factor, whether produced by gastritis, excess of fermentable food or paucity of saliva in the aged. The acid reaction favours the growth of yeasts and filiform acidophilous bacilli, and adhesion of the epithelial scales to each other. Dr. Barber identified three different species of Monilia from hairy tongue as Monilia metatropicalis, Monilia krusei, and Monilia pinoyi. ${ }^{9}$ Dr. Price reported a case of black hairy tongue during autopsy on a 71-year-old man who died from generalized arteriosclerosis. ${ }^{8}$ Whittle in 1946 described black hairy tongue in a 32 aged post office worker who smoke thirteen cigarettes per day. ${ }^{8}$ Waggoner and Volpe in 1967 who reported a prevalence rate of $0.4 \%$ of cases of Hairy tongue. ${ }^{9}$ In 1999 , Manabe et al. using antikeratin probes on black hairy tongue epithelium, found that the "hairs" are highly elongated cornified spines that result from delayed desquamation of the cells in the central column of filiform papillae and marked retention of secondary papillary cells that expressed hair-type keratins. ${ }^{9,10}$ In 2003 Taybos et al reported cases of Black Hairy tongue among smokers. ${ }^{11}$ Arab JP reported case of Black hairy tongue during interferon therapy in the treatment of Hepatitis C. 12 In 2016, Andreas Korber reported a case of black hairy tongue in 85 year-old male cigar smoker. Hairy tongue was reported among old edentulous patients. ${ }^{13}$

Hairy tongue was reported in a 63-year-old-Caucasian man with Amyotrophic lateral sclerosis (ALS) is a dramatic neurodegenerative disease resulting from the degeneration of the upper and lower motor neurons in the brain and spinal cord. ${ }^{14}$ Hairy tongue was reported after a successful stem cell allogenic transplantation for the treatment of Graft vs host 
disease. ${ }^{15}$ Black hairy tongue was reported to exposure to metronidazole antibiotic alone. ${ }^{16}$ Black hairy tongue with a fixed dose combination of olanzapine and fluoxetine. ${ }^{17}$ Black hairy tongue was also reported after Penicillin and olanzapine drug therapy. ${ }^{18,19}$ Antibiotic disrupts the normal bacterial flora favouring the formation of candidal colonies resulting in hypertrophy of filiform papilla. Linezolid, an oxazolidinone antimicrobial drug active against antibiotic-resistant Grampositive bacteria including methicillin-resistant Staphylococcus aureus (MRSA) and vancomycin-resistant enterococci induced Black hairy tongue, as an adverse reaction identified by Naranjo Probability scale.

This defective desquamation prevents normal debridement resulting in excessive growth and thickening of the filiform papillae that then collect debris, bacteria, fungi or other foreign materials which contribute to the discoloration. ${ }^{20}$ Recently a female patient with polymyalgia rheumatica who developed hairy tongue following treatment with prednisolone.21 Hamad Y et al reported black hairy tongue following ingestion of drug Meropenem one week following a polymicrobial infection. ${ }^{22}$

Black hairy tongue was reported after chemotherapy in cases of Brain tumours. ${ }^{23}$ Bonnet $\mathrm{U}$ reported cases of Black hairy tongue following consumption of Lorazepam in patients with severe depression. ${ }^{24}$ Ranitidine, a H2 antihistamine also proved to cause Hairy tongue. ${ }^{25}$ Sakaguchi K reported case of Hairy tongue in patients consuming Tetracycline medications. ${ }^{26}$ Recent studies had stated that Glycopyrrolate, was found to cause Hairy Tongue. ${ }^{27}$

Differential Diagnosis for Hairy Tongue include Oral Hairy Leukoplakia. Oral hairy Leukoplakia is caused by Ebstein Barr virus infection that clinically appears as a white hair like corrugated appearance, which is non-scrapable mostly occurring on the lateral border of the tongue.

Biopsy with Potassium hydroxide mount preparations: Helps in the identification of the tube-like branched hyphae or filaments of oral candida.

Latex agglutination-based card test (Candidasure): A rapid test for the presence of systemic candidal infection based on Latex agglutination.

\section{Newer Diagnostic Modalities for Hairy Tongue}

Widefield optical fluorescence device allows better visualization of the hair like projections of hypertrophied filiform papilla. It is performed with a specialised device with high-power light-emitting diode, emitting light centered at a wavelength of $(400 \pm 10) \mathrm{nm}$ and maximum irradiance of $(0.040 \pm 0.008) \mathrm{W} / \mathrm{cm}^{2}$ was used and images showed fluorescence projections of hair-like elongated filiform papilla. [Figure 5] The autofluorescence were due to the presence of keratin which acts as a fluorophore and can be detected and visualized through the widefield optical fluorescence device.

The main advantage of Widefield optical fluorescence technique include non-invasive, painless, without the need for staining with specialised dyes, it also does not involve the use of ionizing radiation and provides the result in real time. The main disadvantage of Widefield optical fluorescence complementary device was that it requires a dark environment for accurate visualization of the fluorescence, cost, its operator dependent, hence adequate knowledge and professional training in the device is necessary. ${ }^{28}$

\section{Treatment Modalities for Hairy Tongue}

The mainstay for treatment of hairy tongue is done only when patient is symptomatic. For patients with burning sensation in patients with hairy tongue, due to the presence of increased candidal organisms within the hypertrophied filiform papilla, candid mouth paint (1\% clotrimazole) or lozenges or oral troches were prescribed topically for a period of at least 2 weeks, which helps in reduction of the symptoms. Candid mouth paint also helps in reduction of candida microbial overload that also helps in the reduction of oral malodour. The main mechanism of action of topical antifungal action of $1 \%$ Clotrimazole is prevention of growth of candida by bacterial cell lysis by altering the permeability of the bacterial cell membrane by binding to phospholipids in the cell wall of the Bacteria. The high sugar content makes it relatively contraindicated in persons with diabetes. ${ }^{29}$

\section{Nystatin}

Nystatin is a fungicidal and fungistatic antibiotic obtained from Streptomyces noursei, effective topically against various yeasts and yeast like fungi. Nystatin acts by causing changes in the permeability of the fungal cell membrane after binding to cell membrane sterols, causing cytoplasmic contents to leak resulting in cell death. The main adverse effect of Nystatin is due to its high sugar content and licorice flavour to mask its bitterness in lozenges, which prevents its use in patients with diabetes. $^{29}$

\section{Podophyllin Resin}

$1 \%$ Podophyllin resin, a cytotoxic agent that was found to be beneficial in the treatment of Hairy tongue. The use of which is restricted in the treatment of Hairy tongue because of undesirable severe side effect of irritation. ${ }^{29}$

\section{Isotretinoin}

Topical application of isotretinoin gel, a synthetic Vitamin A analogue proved to be beneficial in the management of Hairy tongue. The main adverse effect is it causes atrophy of the mucosa and severe photosensitivity reactions. ${ }^{29}$

\section{Urea Solution}

Urea solution in concentration of $30-40 \%$ prove to be beneficial in the treatment of Hairy tongue, it acts as a potent cytotoxic agent, but its application is also limited due to its adverse effect of cytotoxicity.

\section{Probiotics \\ Yogurt is a fermented milk product obtained from Cow, Goat or Buffalo's milk. Yogurt is produced by bacterial fermentation of milk by Lactobacillus bulgaricus and Streptococcus Thermophiles. The main mechanism of action is by consumption of sugars present in the milk by bacterial species}


Lactobacillus bulgaricus. It provides dietary supplement of protein, calcium, folic acid. ${ }^{29}$

\section{Surgical Treatment Modalities for Hairy Tongue}

Electrodessication or Thermal cautery : Electrodessication of the hypertrophied filiform papilla that were resistant to drugs can be done with the use of electrocautery, a process in which the hypertrophied filiform papilla were destructed by the use of a metal wire in which heat is generated by the passage of alternating or Direct current. ${ }^{30}$

\section{Carbon Dioxide Laser}

Carbon dioxide laser is used for the removal of hypertrophied elongated filiform papilla on the dorsum of the tongue, if other medical modalities of treatment fails. The main advantage of carbon dioxide laser therapy is that it aids in faster healing period than conventional surgical treatment methods. ${ }^{30}$

\section{CONCLUSIONS}

Hairy tongue is usually asymptomatic. Some cases were associated with halitosis, glossopyrosis and dysgeusia (altered taste sensation), and metallic taste. A thorough detailed history is always necessary for establishing the diagnosis and treatment of hairy tongue.

Financial or Other Competing Interests: None.

\section{REFERENCES}

[1] Gurvits GE, Tan A. Black hairy tongue syndrome. World J Gastroenterol 2014;20(31):10845-50.

[2] Cheshire WP. Unilateral Black hairy tongue in trigeminal Neuralgia. Headache 2004;44(9):908-10.

[3] Sementsov II. A case of hairy black tongue in phthisiatric practice. Probl Tuberk 1995;(6):44-5.

[4] Pipili C, Cholongitas E, Ioannidou D. Is sunflower seed implicated in the development of black hairy tongue? Eur J Dermatol 2008;18(6):732.

[5] Pigatto PD, Spadari F, Meroni L, et al. Black hairy tongue associated with long-term oral erythromycin use. J Eur Acad Dermatol Venereol 2008;22(10):1269-70.

[6] Refaat M, Hyle E, Malhotra R, et al. Linezolid-induced lingua villosa nigra. Am J Med 2008;121(6):e1.

[7] Jover-Diaz F, Cuadrado-Pastor JM, Talents-Bolos A, et al. Black tongue associated with linezolid. Am J Ther 2010;17(4):e115-7.

[8] Whittle CH. Black hairy tongue. Proc R Soc Med 1946;39(5):228.

[9] Waggoner WC, Volpe AR. Lingua villosa nigra--a review of black hairy tongue. J Oral Med 1967;22(1):18-21.

[10] Manabe M, Lim HW, Winzer M, et al. Architectural organization of filiform papillae in normal and black hairy tongue epithelium: dissection of differentiation pathways in a complex human epithelium according to their patterns of keratin expression. Arch Dermatol 1999;135(2):177-81.

[11] Taybos G. Oral changes associated with tobacco use. Am J Med Sci 2003;326(4):179-82.

[12] Arab JP, Vargas JI, Morales C, et al. Black hairy tongue during interferon therapy for hepatitis C. Ann Hepatol 2015;14(3):414-5.

[13] Kannan S, Muthusamy S, Chandrasekaran B, et al. Black hairy tongue in older edentulous individuals. J Am Geriatr Soc 2014;62(5):992-4.

[14] Erriu M, Pili FMG, Denotti G, et al. Black hairy tongue in a patient with amyotrophic lateral sclerosis. J Int Soc Prevent Community Dent 2016;6(1):80-3.

[15] Akay BN, Sanli H, Topcuoglu P, et al. Black hairy tongue after allogeneic stem cell transplantation: an unrecognized cutaneous presentation of graft-versushost disease. Transplant Proc 2010;42(10):4603-7.

[16] Kuo S, Fazel N. Black hairy tongue due to metronidazole. Journal of American academy of Dermatology 2017;76(6 Suppl 1):AB56.

[17] Jhaj R, Gour PR, Asati DP. Black hairy tongue with a fixed dose combination of olanzapine and fluoxetine. Indian J Pharmacol 2016;48(3):318-20.

[18] Kanodia S, Giri VP, Veerabhadrappa RS, et al. Black hairy tongue with olanzapine: a rare case report. Indian J Psychiatry 2017;59(2):249-50.

[19] Wolfson SA. Black hairy tongue associated with penicillin therapy. J Am Med Assoc 1949;140(15):1206-8.

[20] Khasawneh FA, Moti DF, Zorek JA. Linezolid-induced black hairy tongue: a case report. J Med Case Reports 2013;7:46.

[21] Uğur S, Kaçar C. Prednisolone-induced hairy tongue: a case report. Arch Rheumatol 2019;34(3):348-51.

[22] Hamad Y, Warren DK. Black hairy tongue. N Engl J Med 2018;379(10):e16.

[23] Yamagishi Y, Maruyama K, Kobayashi K, et al. Black hairy tongue after chemotherapy for malignant brain tumors. Acta Neurochir (Wien) 2017;159(1):169-72.

[24] Bonnet U, Ringel P. Black hairy tongue associated with lorazepam treatment of a male smoker with major depression. Journal of Clinical Psychopharmacology 2017;37(2):261-3.

[25] Akcaboy M, Sahin S, Zorlu P, et al. Ranitidine-induced black tongue: a case report. Pediatr Dermatol 2017;34(6):e334-6.

[26] Sakaguchi K, Watari T. Tetracycline-induced black hairy tongue. J Gen Fam Med 2020;21(3):80-1.

[27] Prabha N, Arora RD, Singh N, et al. Glycopyrrolateinduced black hairy tongue. Indian Dermatol Online J 2020;11(2):256-7.

[28] Powell FC. Glossodynia and other disorders of the tongue. Dermatol Clin 1987;5(4):687-93.

[29] Handler MZ, Butler DF, Eisen D, et al. Hairy tongue. https://epublications.marquette.edu/cgi/viewcontent.cg i?article $=1259 \&$ context $=$ dentistry_fac

[30] Jung DW, Cho E, Ahn HJ. CO 2 Laser application for treatment of the hairy tongue. Journal of Oral Medicine and Pain 2013;38(2).97-101. 